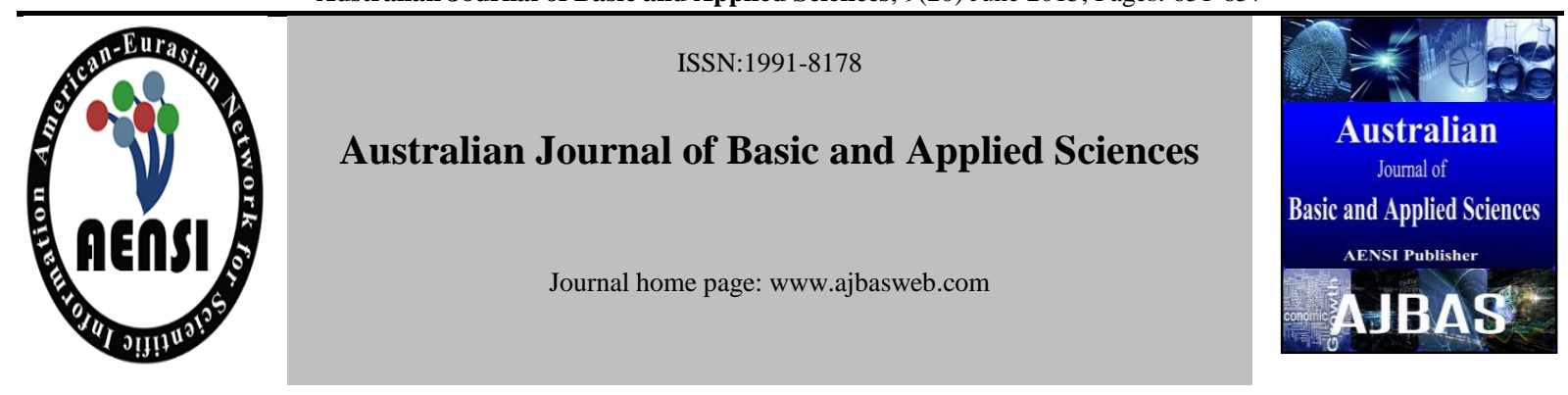

\title{
Religiosity Value in Poetry
}

Muliadi

Muslim Indonesia University, Faculty of Letters, Makassar-Indonesia

ART ICLE INFO

Article history:

Received 12 March 2015

Accepted 22 May 2015

Available online 22 June 2015

Keywords:

Values, Religiosity, Poetry

Hermeneutic.

\begin{abstract}
A B S T R A C T
Poetry as a literary work is a representation of actions and thoughts of creator or poet after struggling with world, both outside and inner world /within himself. Values that born from struggle is very diverse, as philosophical, aesthetic, ethical, and religious value. However, this paper focuses only on aspect of religious values, in particular creed, especially on limitations aspects, hereafter and omnipotence of God. Normal value is also referred to as worth. Values are phenomenal and very distinctive. Value is phenomenal because not everyone has uniform definition about value and very distinctive because not all people give the same assessment to an object observed. Religiosity value is is related with deity or human relation with God and all His creation. This value is found in literary work, especially old literary. Poetry is part of a literary work that also contains religiosity value. Approach to reveal religiosity value in poetry Husni Djamaluddin is hermeneutic Recoeur.
\end{abstract}

(C) 2015 AENSI Publisher All rights reserved. To Cite This Article: Muliadi., Religiosity Value In Poetry. Aust. J. Basic \& Appl. Sci., 9(20): 651-657, 2015

\section{INTRODUCTION}

Poetry as a literary work is a representation of actions and thoughts of creator or poet after struggling with world, both outside and inner world /within himself. Values that born from struggle is very diverse, as philosophical, aesthetic, ethical, and religious. This is consistent with statement of Amir (1986: 193) that good literary work should contain integrity and coherence value, i.e. value of religious, philosophical, aesthetic, and ethical. From these diverse values, this paper only examines religiosity values.

Value is synonymous with Valere in Latin, and valoir in Old French, that commonly called as worth or goodness (Mulyana, 2004: 7). Value that perceived in a certain context will becomes something phenomenal and very typical in human life. It is phenomenal because not everyone agree to give uniform definition to value and very distinctive because not all people give the same assessment to an observed object. For example, two people is offered a nice watch and made of gold. Both men are not necessarily have same vote, probably the first one has good vote and immediately want to have it, while the second one is not good, so he is not interested to have it.

Value means the degree, quality, quality, extent, and nature height of thought, religion, community, and others. This means that the value is high and something valuable, important and very necessary for human life (Alexander, 1998: 864). It is consistent with Gazalba (1998: 33) that value is something to be treasured by man or group of men. Meanwhile, Ali ibn Abi Talib (in al-Qarni, 2008: 178) states that human values are in good deeds that he did. It means that human sciences, culture of decency, worship, generosity, and good character and morality is the real value of self and not the face, style and position. This is consistent with (QS. Al-Baqarah: 221), which means, "Truly believer slave is better than the idolaters, even though she pulls your heart."

Religiosity value is related with deity or human entanglement with God and all the creation. This value is found in literary, especially in old literary. Many primitive societies, at beginning of creating a literary work to benefit of worship or certain ceremonies that are sacred. In course of human history, literature was always in contact with dimensions of religious values.

Religiosity issue in Muslim community is a very complex issue because it not only covers the human relationship with God, but also man's relationship with man, and man's relationship with nature (hablum minal basyariah). In Islamic perspective, concept of religious values generally divided into three, namely concerning the subject of (a) faith, (b) Islam, and benevolent. In connection with these values, Al-Jazairi (2003: 25) divides the concept of religiosity value as things pertaining to (a) belief, (b) worship, and (c) muamalah. 
Creed or belief is also known as faith; faith means a bond, soul bond. Someone who believes heart and feelings tied to a belief will no longer exchangeable with other beliefs (Kaelany, 2000: 58). Worship is an act to express devotion to God based on obedience to His commands and avoid His prohibitions. Muamalah is related to social issues. Muamalah represent value of faith and worship to govern the harmony of living together between man and man, between man and natural environment within divine network.

Three parts of religiosity value mentioned above are creed, worship, and muamalah. However, this paper only discuss creed and the related value is only to aspects of limitations, hereafter, and omnipotence of God. The each breakdown is associated with poetry. Poetry as data source is the poetry of Husni Djamaluddin. Husni Djamaluddin (HD) is a poet from South Sulawesi which goes national (Muliadi, 2014). He is dubbed as the "Commander of Poetry" for the poet of South Sulawesi because the diligence and agility to arrange words into a poem and loyalty to create poetry where at end of his life still had time to write poetry, when he was referred to Gatot Subroto Army Hospital, Jakarta. A poem prior to last breath is below.

WHAT PEOPLE

ABOUT HPH conglomerate

The entire area of this forest

We have it

Except

The trees

August 17, 2004

\section{Approach:}

Ricoeur's hermeneutic approach is used in this paper to uncover the meaning or values contained in HD poetry. According to Ricoeur, hermeneutics is theory about rules of interpretation of a particular text or set of signs and symbols that are considered as text (Suratno, 2005: 105). Hermeneutics try to dispel the mystery within symbols or text by uncover the veil of unknown and hidden in symbols or text.

Ricoeur (2006) stated that a text is autonomous or stand-alone and does not depend on intent of author. Ricoeur statement is consistent with poststructuralist, like Savoj Žižek (in Kristiatmo, 2007: ix) about autonomy "writing" by saying "subject already dead". Because the text is autonomous, then the text is also not depend on a historical work or book where the text listed.

Ricoeur's Hermeneutics need an allegation to estimate other. This is due to the text contains a plurality of inherent meaning which allows interpreted in various ways. This indicates that interpretation is open process, but by no means arbitrary and capricious. In conducting in-depth interpretation, interpreter enters to world of text, following the movement of understanding to another meaning (referential), from internal structure to projected world (Rafiek, 2010: 6).

Ricoeur's hermeneutics work steps are as follows: (1) symbolic step or understanding of symbols to symbol, (2) giving the meaning to symbols and meaning with accurate exploration, (3) a step that really philosophical, which is thought by using symbols as a starting point. These all three steps are closely related to language comprehension measures, i.e. semantics, reflexive, and existential or ontological (Sumaryono, 1999: 111). All three steps are used to reveal religiosity value poetry of Husni Djamaluddin, namely limitation, existence of God, and Hereafter.

\section{Human Limitations:}

Limitations aspect in poetry of Husni Djamaluddin is found in following data.

\section{Data 1:}

if at the end the eyes were closed and body motionless what else the rest

\section{Data 2:}

perhaps I will travel long distances

perhaps I can pass shortcuts

perhaps I could soon be in front of Your house

You're probably willing to open the door

You might deign to give the hand

You're probably smile to said: go in

Data 1 and data 2 come from the poem "if at the end". Semantically, the end means no other days or there is no longer thereafter; the eyes were closed means the eyes already closed, do not see; motionless body means can not or difficult be bent; perhaps indicating doubt or uncertainty about one thing; the word "I" can become an icon of HD and can also be an "I" as lyrics; Your house / You are a symbol refers to God Almighty. This is because You and Your is written with a capital letter and is supported by words and phrases: perhaps I will travel long distances, perhaps I can pass shortcuts, perhaps I could soon be in front of Your house, You're probably willing to open the door, You might deign to give the hand, You're probably smile to said: go in.

Reflexively, above data indicate that all animate beings, including "I" as lyrics or "I" as HD will die, as seen in array (the eyes were closed and body motionless). In such circumstances, die people hope charity, useful knowledge, and pious children who pray for his parents. Death problem death is included as rana sara in panngaderreng system of BugisMakassar tribe. Tribe or community of BugisMakassar and other tribes in South Sulawesi have long believed about death, i.e., since the pre-Islamic era. It appears in Sure 'Galigo, that man's fate has been determined by Gods, in language of Sure' Galigo is called Pattoto-e (He who determine the 
fate); including death for every living creature on this earth (Mattulada, 1995: 59). Therefore, it can be said that before Islam arrived in South Sulawesi, South Sulawesi people believe in God Almighty. With existence of such belief, South Sulawesi facilitate acceptance of Islam.

Existentially, Data 1 and Data 2 show that I as lyrics or $I$ as $H D$ is the servant of God with limitations to maintain its presence as a living creature. As living creature, he is going to die, as we see and reinforced in (Surah Ali Imran: 185) Kullu Nafsin Zaaikatul Maut (which means: all animate beings will die).

Generally, human life is divided into two, namely the life in world and in hereafter. Life in world is temporary, as we have seen, while the Hereafter is permanent because no dead people can come back to world. Hereafter life is supernatural, but we believe the truth as in Islam teachings. Rabbana aatina fiddunya khasanah wa fil akhirati khasanah, wa kina azabannar. It means, "O Allah give us the live happiness in world and live happiness in hereafter, and we take away from of Your hell torment.

Data 2 above offer hope and at same anxiety for every human being that if he quickly reached by God or he was left out along the road that is very far away, with a full tremendous torture. It depends on charity and worship during the time given of opportunity to live in world. In Koran, Sura 99, verses 7 and 8, which means: So whoever does an atom's weight of good will see it, And whoever does an atom's weight of evil will see it.

Data in relation with limitations or human destiny is presented implicitly by HD in his following poem:

Data 3:

is still useful to read the incantation when the sun broke in head is it still useful to write poems when the sun was torn in chest is it still useful to say a prayer when the sun melts in heart

I do not know how you

when the sun broke in your head

when the sun melts in your heart

Data 3 above comes from a poem entitled "Is still useful". Semantically, pray is a symbol request servant to God; the sun is a celestial body, center of solar system in form of gas-filled balls that bring light and heat to earth during the day; rupture means broke into several parts; means torn apart or disconnected; melt mean flow (tears, sweat, and so on); I was on icon (HD) and "you" are interlocutors of HD.

Reflexively, above data indicate that sun as a celestial body can become a symbol of life and can also become a disaster or horror, as in data 3: the sun broke in head, the sun melts in heart, and the sun melts in your heart.

Sun in this data is known as a symbol of something very hot, very terrible thing for the "I" and "you". It is understood that sun as an object that is very hot and terrible because it was followed by broken lines in head, torn in chest, and melt in heart. In South Sulawesi society, a statement like that is often raised by cleric when he was lecturing and parents when he was advising his son, especially "naughty" children. Bugis said "esso rimunrinna puang e, si jakka mani matanna esso e pole ri ulu e" (in hereafter of God, sun only one above head). The purpose of advice or proverb above are to hope the listener can repent and doing alms in order sun heat in Hereafter become cool because of alms in the world.

Existentially, data 3 shows that "I" and "you" are in a very weak position and very frightened in face of other objects, sun that very hot.

"I" was in doubt and pessimistic about the efforts and prayers performed in emergency or sudden condition. Advice from old people or pious in South Sulawesi stated that repentance is no longer useful when the death come (already in throat). This is consistent with history that "repentance door already closed when someone almost death or breath has reached the throat." This history is reinforced in (Qur'an, An-Nisa: 18) " But repentance is not [accepted] of those who [continue to] do evil deeds up until, when death comes to one of them, he says, "Indeed, I have repented now," or of those who die while they are disbelievers. For them We have prepared a painful punishment."

Other data related to human limitations is follows:

\section{Data 4:}

too fast

time passing

too little

was assembled

the skies

still narrow

My place I peek

whole Thou

Data 4 above is from poem with the title "Two poems without title". Semantically, time refers to time to do something; I refer to HD icon; Thou are a symbol of owner of time (God).

Reflexively, time never stops for a moment; he goes in accordance with rules set by owner (God). $\mathrm{HD}$ as a servant of God has limitations because unable to slow down or speed up the time.

Existentially, data above is understood that time is running in according with Creator will, and therefore time there must be utilized if it does not want to lose or regret, as stated in (Surah Al-Asr: 13) 1) By time, 2) Indeed, mankind is in loss, 3) Except for those who have believed and done 
righteous deeds and advised each other to truth and advised each other to patience. If the first verse speaks about time that is so quick, on second verse speaks about a space so narrow compared with Thou.

Thou and sky word at above data are symbol, while the word my place I is the icon to show HD himself. Thou are a symbol of God's word, which is very vast. Thou is said as God because it written in capital letters, HD very disciplined in using pronouns for God. If the pronoun for God then he always use a capital letter at beginning of pronoun. Conversely, if it is only pronoun then simply written with small letters. The sky is said to be a symbol as well as demonstrate the vast seemed boundless, but when it is confronted to Thou (God) then the "I" (HD) feel the sky is still narrow. It means that God is all over everything.

The believers will continue to do good works and feel the time and space for them very short and narrow because having many dream to achieve, but have not or do not realized.

\section{Existence of God:}

Husni Djamaladin poetry shows some data to speak about existence of God as following.

\section{Data 5:}

in river water there is Thou

in sea wave there is Thou

in breeze there is Thou

in storm there is Thou

in a steep valley is Thou

the towering mountain there is Thou

in moonlight there is Thou

in sun there is Thou

in arid desert there is Thou

in cold snow there is Thou

in roses bloom there is Thou

in pouring rain there is Thou

in tiger catch in there is Thou

in cats miaow there Thou

the eagle fly there is Thou

the chirping of turtledoves there is Thou

the jewel sparkle there is Thou

in silence stone there is Thou

in lover smile there is Thou

in "I" there is Thou

in Thou

I was amazed

Data 5 comes from a poem with the title "If Thou are a river flows." Semantically, river is a large water flow and usually made by nature; the sea is a collection of salted water (in a large number and wide) that bathes and divides the land on continent or island ; wind is the movement of air from areas of high pressure to areas of low pressure; storms are strong winds that accompany bad weather (which comes suddenly); valley means lower ground; mountains means very large and high hill; the moon is a celestial body that around the earth, shining at night because reflection of sunlight; the sun is a celestial body, center of solar system in form of gasfilled balls which bring light and heat to earth during the day; the sand grains are smooth stone; snow is grain moisture white like cotton that freezes in air and fall to ground due to air temperature in area at below freezing; rose is shrubs plant of Rosaceae family; rain is falling water from the air as cooling process; tigers are wild animals, meat eaters, it seems like a big cat; cat is an animal that looked like a little tiger; eagle is a predator bird with sharp eyesight, hooked beak and strong grip, catch their prey by grabbing; turtledove is ketitir bird, size of body length is approximately $10 \mathrm{~cm}$, the color is gray and blackish throughout the body, black beak, and short legs; gem is precious stone with beautiful color (like diamond, sapphire); rock is hard and solid objects that come from the earth or another planet; lover means saying or feeling of love; Thou word refer to God that written with a capital letter; "I" is icon of Husni Djamaluddin; fascinated means interested heart.

Reflexively, repetition words above are very rich in HD poetry, as word "in" with much variation word to follows and repeated twenty-one times and "Thou" also repeated twenty one times. This repetition it can give effect to saturation, but on other hand it may also become a power evocation for readers of poems HD and can also become a symbol of poet's breadth of knowledge. Poet smartly string words that indicate a binary opposition between the Creator with the creation so that reader of this poem directly aware of God's wisdom. Other binary opposition is: between soft with hard/terrible, like a gentle breeze by storm; between cool and heat, like the moon and sun; between the beast/tame wild animals, such as tigers catch and cats miaow; between birds spooky with beautiful birds, such as hawks with chirping turtledove; between objects that sparkling with ordinary objects, such as gems and silence stone.

The objects existence makes the "I" (HD) interested or impressed to Thou / Creator of entire universe.

Existentially, data 5 show figure of nature and properties attached to it, as well as the existence of God Almighty with His presence at everywhere, including within "I" lyrics or "I" (HD), as indicated in end section, namely in I there is Thou.

Other data show existence of God as follows.

Data 6:

has dried all ocean ever wavy

Reserved into my soul to search Thou

Data 7:

Go far away

Getting farther

Horizon limit

The more I approached 
growing pains

sun thermal

will continue

wander

be

Ask

Him

Data 6 comes from a poem entitled "Finding Thou". Semantically, dry means have been exhausted, or even the slightest remaining (on water); "I" was on icon HD: Thou is symbol of God as written in capital letters and accented with lines or words that preceded it, namely: has dried all ocean ever wavy, Reserved into my soul to search Thou

Reflexively, data 6 shows that there is searching and there is searched, searcher here is "I" lyrics or I (HD) and the searched is Thou (God).

The group has dried all ocean ever wavy at data 6 is an index of data to show that the water exhausted and no surging sea once again because the water has been depleted absorbed by "I" (HD) to search Thou. Thou that he means is God and data 6 also show that "I" (HD) really search God.

Therefore, data 6 very relates with data 7 (a poem entitled "Ask Him"), which indicates that "I" (HD) search God through many obstacles and challenges, without know much less tired and desperate. This is a sunnatullah a provision of God) that pleasure or happiness can be achieved by a servant when the servants first should work or try. For example, food is in front of us, we can not feel delicious or ecstasy before inserting into mouth and chew it and swallow it. It is consistent with (QS. Alam Nasyrah: 5-6) With every difficulty there is relief; verily with every difficulty there is relief.

Existentially, based on data 6 and data 7 above, "I" (HD) to "close" and/or "meet" with God then he performs a variety of ways, reading of his creation and or write it down, and worship him. We still not read all nature of his creation, our live already taken by by Angel of Death and similarly we have not finished to write his wisdom and knowledge. In fact, if assume that sea water can be used as ink and trees on this earth can be used as a pen, then dried seawater and discharged trees were cut down, science of God will never dry or depleted. So broad and not limited wisdom, grace, knowledge of God that was likened to ocean is dry, but not yet completed the sentence of God, as in (Surah al-Kahf: 109) " Say, "If the sea were ink for [writing] the words of my Lord, the sea would be exhausted before the words of my Lord were exhausted, even if We brought the like of it as a supplement."

Every human being, especially Muslims, to seek Allah's acquiesce should be taken seriously and never hopeless, although there are many obstacles/challenges. Other data to talk His existence is below.
Data 8:

I match

with God

in a boxing ring

without rope

without audience

without referee

without anything

Data 8 data comes from a poem entitled "The match with Lord". Semantically, "I" is icon of HD; God is a symbol of Creator or Supreme Ruler; match means competing in a race or power match.

Reflexively, above data refer to "I" compete with God in a state of quiet. The presence of "I" the "God" in data due to compete as an index word about the existence of two camps, namely "I" as a servant, being created and God as Creator. Meanwhile, match word raises other icons, in a boxing ring, without rope, without audience, without referee, without anything

Existentially, Data 8 can be interpreted that "I" when he want to be "closer" and or "meet" with God, should be done in quiet condition. When connected with religion of Islam that quiet state can be defined as middle of night when all other people are sleep. Waking up to take ablution for pray or facing Him with humility, with submission of all body and soul just for him.

\section{Hereafter:}

The data about Hereafter is follows.

\section{Data 9:}

at estuary, I am the river Thee the sea

at estuary, I am come Thee who call

at estuary, I am come back and You pinch

what estuary

where estuary

estuary name is

death

Data 9 data comes from a poem with title "The Estuary". Semantically, estuary indicates the index of meeting between river water and sea water. From the estuary comes another index, river and sea. A river water flows from the high land to low land either straight or winding, while the sea is a vast water, broad, deep, and wavy.

Then it is also known that from estuary there is "I" icon and and Thou symbol. "I" is a representation of "I" lyrics (HD) as servants, while "Thou" is representation of God Almighty. Thou word in data 9 is understood as the ruler because besides written with a capital letter also refers to words, both words that precede and follow it word, for example: at estuary, I am the river Thee the sea.

Reflexively, data 9 above shows that "I" thought himself as a river and Thou (God) is positioned as a marine and estuarine positioned as death.

Existentially, data 9 is understood that someday "I" will get back to Thou through estuary (death). A 
Muslim must believe that eternal life is the life in hereafter. World life is temporary, life to seek provision towards eternal life, a place where people undergo the testing process and Islamic faith and faith to God. World life is temporary, as described in (Surah ar-Rahman: 26-27) "Everyone upon the earth will perish. And there will remain the Face of your Lord, Owner of Majesty and Honor."

HD's poetry has a very prominent characteristic, namely repetition. Repetition usage may cause boredom for readers of his poetry, but on other hand repetition actually provide a strong accent to support the mandate contained in it. As in data 9, estuary word so that meaning of word estuary is actually clearer. Estuary is called death. Death is something that is feared by man, but he can not avoid it because death will surely come at time and place specified by the Most Determinant, God, as in Prolegomena (Qur'an, al-Qasas) stated that " And your Lord creates what He wills and chooses; not for them was the choice. Exalted is Allah and high above what they associate with Him. And your Lord knows what their breasts conceal and what they declare".

\section{Data 10:}

until arrive

hour of twenty five

last hour

for whole day

no more one hour

no twenty four hour

no new day

no past day

no hour

no minutes

no seconds

only there is centuries

that never ending

centuries of silence

for those who do not have a Lover

Data 10 comes from a poem with title "Hour of twenty-five". Semantically, hour shows the time period or indicate the length of time and hour can also refer to object, for example, who is owner of the nice watch? However, in context of data 10, hour more refer time that the thing.

Reflexively, lines which reads hour of twenty five is rater messed up the reasoning of reader because the reader understands that hour in a day and night just twenty four hours. However, with regard to next phrase, last hour // for whole day, then the reader's mind has begun arrive to another thought, time or hour is time in hereafter. This was confirmed by following verses: no more one hour // no twenty four hour // no new day // no past day // no hour // no minutes // no seconds // only there is centuries // that never ending // centuries of silence // for those who do not have a Lover. This line is an index of time after this life, time in Hereafter. Hereafter no more seconds, minutes, hours, days, weeks, months, and years, only there are centuries that never end.

Existentially, data 10 indicates that human life has been determined by Beloved (God) and when last age has been determined comes, then the respective ends also the days, no more no calculation of seconds, minutes, hours, days, months, and year, there are centuries never end, silent centuries for no Lover.

Silent centuries for which no lover insists that human death is very silent and terrible, except they who have Lover. Lover word is begins with capital letters indicate the Creator. So, people who "have" or "close" to Creator, in here after will always be entertained and favors forever in eternal, endless because it is the last place designated by mankind (Islam), which believe to Hereafter.

\section{Data 11:}

I am out of sun when the emergency door open I am greeted with official smile of sea horse welcome to sea country

You should see, I am the death

I am ushered into a magnificent gate

and said

That beautiful blood red castle rock

but not your place because your name is not written there

and I asked

where I would be brought

and sea horse was pointing to one place

vaguely visible

between green sea grass and coral clusters

that your house

you've built in earth

with your own sweat

Data 11 comes from a poem entitled "I and Sun". Semantically, it was discovered that "I" is icon of $\mathrm{HD}$; the sun is a symbol of life; sea horse symbolizes of death (Angel of Death). Data 11 also shows that death greet and bring me to beautiful blood red see castle rock and green coral clusters. Among the two palaces or places designated by sea horse (death), then my place is green coral group because that is what has been built while still on earth.

Reflexively, these data refer to man in next place associated with behavior and actions in world. If the behavior good, then he will get a decent place and vice versa, if behavior and actions are not good, then he will get a place same as his behavior.

Existentially, data 11 show that die person is depend on charity while still living in world. If you often do well in accordance with guidance of religion (Islam), this person will get a decent place or replied with Allah Almighty. God through His angel records all his servants deeds, both good deeds and bad deeds, large and small, as in (QS, an-Nisa ': 40) " Indeed, Allah does not do injustice, [even] as much 
as an atom's weight; while if there is a good deed, He multiplies it and gives from Himself a great reward."

\section{Conclusion:}

Data 1 up to 4 data show that all refer to limited ability or willingness of beings (humans) in realizing his wish, although with different presentation. Humans are not able to do anything except with His will, as in Surah al-Fatihah: 5 declared " It is You we worship and You we ask for help."

Thus, although humans are best creatures or the most perfect creation of God than any other creature, man does not have indefinite ability or power. In other words, human beings have limitations.

Data 8 to 9 data show that God exists at everywhere, including inside the "I" lyrics or "I" (HD) and to get His willingness, "I" need to be patient and submissive because many challenges and obstacles will come. God is very close to "I" or to all of us (human beings), as in (QS, Qaf: 16) " And We have already created man and know what his soul whispers to him, and We are closer to him than [his] jugular vein."

The God existence is not bound by space and time, His existence is in accordance with His will. Every Muslim must believe it is because aqidah or faith is first time instilled to a Muslim, then followed by worship and muamalah.

Data 9 through 11 show that life of Hereafter is the last terminal of travel destination of human beings. At that day the calculation of charity and sin of human is done. People with more charitable than his sin will get a decent place in sight of Allah SWT. And conversely, people with many sins than charity will be processed in accordance with provisions of Him before getting a decent place (comfortable).

Hereafter is the last time or the last place that will be addressed by all human, especially Muslims, who believe to existence of these days. On this day humans will also be collected from the first man, Prophet Adam until the last of Adam grandchild.

\section{REFERENCES}

Al-Jazairi, A.B.J., 2003. Ensiklopedia Muslim (Minhajul Muslim). Diterjemahkan Fadhli Bahri. Jakarta: Darul Falah.

Al-Qarni, A., 2008. La Tahzan (Jangan Bersedih). Terjemahan Samson Rahman. Jakarta: Qisthi Press.

Amir, H., 1986. Nilai-Nilai Etis dalam Wayang dan Pendidikan Watak Guru.. Disertasi tidak diterbitkan. Malang: Program Pascasarjana IKIP.

Gazalba, S., 1998. Sistematika Filsafat III. Jakarta: Bulan Bintang.

Iskandar, T. 1998. Kamus Dewan. Kuala Lumpur: Dewan Bahasa dan Pustaka.

Kaelany, 2000. Islam, Iman, dan Amal Saleh. Jakarta: Rineka Cipta.
Kristiatmo, T., 2007. Redefinisi Subjek dalam Kebudayaan. Yogyakarta: Jalasutra.

Mattulada, 1995. Lotoa: Satu Lukisan Analisis terhadap Antropologi Politik Orang Bugis. Ujung Pandang: Hasanuddin University Press.

Muliadi, 2014. Nilai Multikultural Teks Puisi Husni Djamaluddin dalam Kajian Hermeneutika. Disertasi tidak diterbitkan. Malang: PPs UM.

Mulyana, R., 2004. Mengartikulasikan Pendidikan Nilai. Bandung: Alfabeta.

Rafiek, M., 2010. Teori Sastra: Kajian Teori dan Praktik. Bandung: Refika Aditama.

Ricouer, P., 1981. Hermeneutika Ilmu Sosial. Terjemahan Muhammad Syukri. 2006. Yogyakarta: Kreasi Wacana.

Ricouer, P., 2003. Filsafat Wacana. Terjemahan Masnur Hery. Yogyakarta: IRCiSod.

Sumaryono, E., 2005. Hermeneutika: Sebuah Metode Filsafat. Yogyakarta: Kanisius.

Suratno, 2005. Pluralisme Agama dalam Hermeneutika Paul Ricoeur. Jurnal Universitas Paramadina, 4(1): 105-110. 